UDC 331.5

\author{
A. Kvitka, \\ Doctor of Pbilosopby in Economics, associate professor, Deputy Director of the Educational \\ and Scientific Institute "Karazin Business Scbool", V. N. Karazin National University, Kbarkiv \\ ORCID ID 0000-0002-5730-1352 \\ A. Kramarenko, \\ Doctor of Philosopby in Economics, senior lecturer of tne Department of Management and \\ Administration of the Educational and Scientific Institute "Karazin Business Scbool", \\ V. N. Karazin National University, Kbarkiv \\ ORCID ID 0000-0001-5987-1247
}

DOI: $10.32702 / 2306-6814.2019 .20 .35$

\title{
LABOR MARKET IN THE CONDITIONS OF GROWING DIGITALIZATION OF SOCIETY
}

\author{
А. В. Квітка, \\ к. е. н., доцент, заступник директора ННІ "Каразінська школа бізнесу", \\ Харківський національний університет імені В. Н. Каразіна, м. Харків \\ А. О. Крамаренко, \\ к. е. н., старший викладач кафедри управління та адміністрування ННІ "Каразінська школа бізнесу", \\ Харківський національний університет імені В. Н. Каразіна, м. Харків
}

\section{РИНОК ПРАЦІ В УМОВАХ ЗРОСТАЮЧОЇ АІАЖИТААІЗАЦІЇ СУСПІАЬСТВА}

The digital transformations that are manifested in the abolition and creation of jobs in different sectors, the emergence of new forms of labor and the changing landscape of trade have been investigated. It is shown that the development and implementation of computer technologies have led to the destruction of established industrial relations, and to the creation of new jobs, which before simply did not exist. The impact of new technologies on improving productivity, reducing prices and increasing supply in the consumer market was studied. The dynamics of the enterprises' need in personnel in Ukraine is analyzed. It was concluded that the share of information and communication technologies, trade, consulting, business services in the structure of employment in Ukraine has increased significantly. It is shown that for effective work in the conditions of digitalization firms need specialists with skills of planning and quick decision-making, as well as those who are able to establish cooperation between teams and more confident charismatic leaders. The article emphasizes the actualization of the issue of development of digital skills of the population in the course of increasing penetration of digital technologies into various sectors of the economy. It is found that the skills demanded by the digital society provide opportunities for faster advancement and create conditions for the polarization of society both in terms of income and social belonging. It is proved that digital skills training is an important point for both potential users of new products and services and potential suppliers of innovative technological goods. The possibilities that allow firms to divide tasks in a new way, increasing the time of labor use, are analyzed. The positive (digital services online, low labor costs and greater access to the global pool of virtual workers) and negative (lower level of social security for workers, higher income volatility, greater responsibility for skills development) aspects of the spread of digital technologies are shown. New competitive factors in the transformation of the structure of professions and education profiles are highlighted. Special attention is paid to the growing influence of technology on the processes of interpersonal relations and changes in the social type of a person.

Досліджено цифрові перетворення, які проявляються у скасуванні і створенні робочих місць у різних секторах, виникненні нових форм праці і зміні ландшафту торгівлі. Показано, що розробка і впровадження комп'ютерних технологій призвели як до руйнування усталених виробничих відносин, так і до створення нових робочих місць, яких до цього просто не існувало. Було 
вивчено вплив нових технологій на підвищення продуктивності праці, зниження цін і зростання пропозиції на споживчому ринку. Проаналізовано динаміку потреби підприємств у кадрах в Україні. Було зроблено висновок щодо помітного збільшення частки сфери інформаційних та комунікаційних технологій, торгівлі, консалтингу, бізнес-послуг у структурі зайнятості України. Показано, що для ефективної роботи в умовах диджиталізации фірмам потрібні фахівці, що володіють навичками планування і швидкого прийняття рішень, а також ті, хто здатний налагодити співпрацю між командами і більш впевнені харизматичні керівники. Підкреслено актуалізацію питання розвитку цифрових навичок населення в ході все більшого проникнення цифрових технологій в різні сектори економіки. Виявлено, що навички, затребувані цифровим суспільством, дають можливості для більш швидкого просування і створюють умови для поляризації суспільства за рівнем доходів, так і за соціальною приналежністю. Обгрунтовано, що навчання цифровим навичкам є важливим моментом як для потенційних користувачів нових продуктів і послуг, так і потенційних постачальників інноваційних технологічних товарів. Проаналізовано можливості, які дозволяють фірмам по-новому розділяти завдання, збільшуючи час використання праці. Показано позитивні (цифрові послуги онлайн, низькі витрати на робочу силу і більш широкий доступ до глобального пулу віртуальних працівників) і негативні (більш низький рівень соціальної захищеності працівників, більш висока волатильністьдоходів, велика відповідальність за розвиток навичок) сторони поширення цифрових технологій. Виділено нові конкурентні фактори в рамках трансформації структури професій і профілів освіти. Особливу увагу приділено зростаючому впливу технологій на процеси міжособистісних відносин і зміну соціального типу людини.

Key words: digital transformation, information and communication technologies, digital skills, employment structure, social protection of employees.

Ключові слова: иифрові перетВорення, інформаційні та комунікачійнітехнології, иифрові наВички, структура зайнятості, соціальна захищеність працівникіВ.

\section{INTRODUCTION}

The digital age poses many questions to humanity, particularly about the future of people and their place in the digital world. What skills will labor market participants need to succeed in the competition for popular jobs and high earnings? What is the role of government and business in providing these skills? What business models will be most effective in the digital economy? The need to find an answer to these questions makes the topic of this study relevant.

\section{LITERATURE REVIEW}

Digital transformation in the economic sphere raises many questions about the trends and directions of these changes. One of the areas of restructuring is labor relations related to issues of hiring, current skills, social security and income volatility [1]. Separate studies are devoted to the structure of professions and their demand in the labor market [2]. Digital employment issues are also in the sphere of researchers' professional interest [3]. However, many of these issues require separate study and generalization.

\section{PURPOSE OF ARTICLE}

Since many issues related to the development of the labor market in the current conditions of the growing influence of digital technologies are not only relevant, but insufficiently studied, the purpose of this article is to study the issues related to:
- change in the structure of demand for labor;

- state regulation of the labor market in the new conditions;

- problems and prospects of strengthening the impact of innovation on labor relations.

\section{RESULTS}

Over the past decade, four out of every ten jobs have been created in sectors with a high degree of digital intensity, and with them new forms of work have emerged [1]. All this is a consequence of the digital transformations that are manifested in:

- abolition and creation of jobs in different sectors;

- emergence of new forms of labor;

- changing trade landscape.

At the same time, 100 years ago it was difficult to imagine the professions that are widespread today. The development and implementation of computer technology has led to the destruction of established industrial relations, and to the creation of new jobs, which before simply did not exist. However, modern digital technology allows more products and services to be produced with fewer workers, putting some workers at risk of unemployment or lower wages [4]. In contrast, new technologies contribute to increased productivity, which in turn can lead to lower prices and increased supply in the consumer market through the creation of new products. As a consequence of the above, higher final demand and higher 
employment, and possibly higher wages, can lead to a rebalancing.

Experience shows that labour-saving digital technologies have a significant impact on employment, and new jobs and employment opportunities are slow to emerge. This is evidenced by the dynamics of the needs of enterprises in personnel in Ukraine. In 2000-2012 there was a decrease in demand for labor almost three times. However, the number of economically inactive population fell by almost $20 \%$ during 2010-2018. Main reasons for this are still education and housekeeping. Indicative in this context is that in 2000-2018 in the structure of the economically inactive population decreased the role of:

— pupils and students - from 26.5 to $20.9 \%$;

- those who do not know how to find a job - from 0.9 to $0.1 \%$;

- those who are hopeless to find a job - from 4.6 to $0.6 \%$ [5].

At the same time, the share of information and communication technologies, trade, consulting and business services in the structure of employment during 2000-2018 has increased significantly [5].

However, it is worth noting that the new jobs provided by digital technologies require different skills. These may be skills of a purely technical nature, such as software development and web design. But along with this, competencies that have little to do with digital technologies are very popular. For effective work in the conditions of digitalization firms need:

- professionals with planning and quick decisionmaking skills;

- those who are able to establish cooperation between teams;

- more confident and charismatic leaders.

Working in the field of online marketing and promotion in social networks requires performers of other qualities than those who personally interact with customers. Thus, digital technologies are reshaping the business models of firms, focusing on the creation of "soft skills" [4]. At the same time, effective problem solving and communication skills become priority areas of recruitment.

The second place in the list of vacancies that employers find difficult to fill is occupied by "IT specialists". Meanwhile, the overall ICT skills of many workers who use ICT in their daily lives are insufficient, as are basic ICT skills such as problem solving and communication, which are becoming increasingly necessary to adapt to changing workplaces [2]. According to research, only $31 \%$ of adults have sufficient problem-solving skills to succeed in the world of ubiquitous technology [1].

In the course of increasing penetration of digital technologies in various sectors of the economy for enterprises, spheres of economic activity and national economies, the issue of development of digital skills of the population becomes urgent due to the need to increase competitiveness, increase profitability and for economic growth. In the light of the development of e-Commerce and Internet banking on a global scale, it is also necessary to have adequate skills of the effective use of ICT in everyday life.

However, many people do not have the skills for the digital world. According to OECD data, less than $40 \%$ of those who use sof tware at work every day have the skills needed to use digital technology effectively [4]. At the same time, those who possess the skills demanded by the digital society have opportunities for faster advancement, which creates conditions for the polarization of society both in terms of income and social belonging. According to the research, digital technologies have increased the demand for highly skilled and low-skilled labor, while reducing the interest in mid-level personnel. However, the degree of polarization in the labor market and the degree of gradation of wages as a result of the advancement of digital technologies remains a little studied problem.

In light of the above, the development of skills and interaction with digital technologies is in the interests of both the state and business. For business, the main issues of digital education are:

- increase confidence;

- productivity growth (especially for small and medium-sized enterprises).

Within the framework of national economies the main priorities are:

- promotion of business dynamics;

- structural changes;

- stimulation of investments in intangible assets [1].

Therefore, it is important to teach digital skills to both potential users of new products and services and potential suppliers of innovative technological goods. At the same time, the main issue for suppliers of goods is the establishment of a rational balance between flexibility and mobility, which raises the problem of restructuring and revision of the basic principles of labor relations.

In an era of digital transformation, changing work relationships is one of the key aspects of living standards policy. The impact of digital technology goes beyond employment and skills, it is reflected in the changing organization of work. Modern technologies provide firms with opportunities to divide tasks in a new way, increasing the time of labor use. Innovative online platforms, new intermediary firms connect individual suppliers to individual customers (and of ten in different locations), thus creating a full-time, round-the-clock work schedule focused on an uneven flow of "on-demand" tasks. The development of this trend leads to the transformation of traditional relations between employer and employee and is reflected both in the labor market and in the social dialogue [4]. In general, the consequences can be both positive and negative. The positive effect can manifest itself as follows:

1. Online digital services (data entry, administrative support, programming, legal advice or business consulting) can balance supply and demand in different countries.

2. For firms, lower labor costs and greater access to a global pool of virtual workers can create an opportunity for increased investment in upgrading tangible and intangible assets.

The negative impact of the spread of digital technology is evident in the fact that greater flexibility in the choice of working hours can mean:

- lower level of social security for employees;

- higher income volatility;

- greater responsibility for skills development [4].

Together with the change in demand for labor in the world there is a change in the structure of employment by 
sectors of the economy. Along with the reduction of employment in agriculture (primary sector) and the industrialization of the economy, there is an increase in the proportion of workers in the tertiary sector. According to the OECD, between $75 \%$ and $85 \%$ of the total workforce is currently employed in the tertiary sector, compared with between $30 \%$ and $45 \%$ of the workforce in the mid-20th century in services and high technology [3].

The digitalization of economic activity and the emergence of new network enterprises have increased the turnover of resources. New management methods have changed and increased the speed of financial transactions [3]. Thanks to the availability of new information technologies, the software helps to quickly generate effective solutions. Technological transformations contributed to the transformation of the structure of professions and education profiles. In particular, according to research, between 1980 and 2012 there has been a steady increase in social and mathematical competencies within various professions.

The logistics revolution has brought new competitive factors such as:

- new communication networks;

- cognitive skills;

- creativity in research and R\&D;

- complexity of goods/services;

- new forms of education;

- additional education.

A separate question for the study is how comfortable is the digitalization of all spheres of social life for the people themselves. The growing influence of technology on the processes of production, trade and interpersonal relations is manifested in the change of the social type of a person. These changes are reflected in the theory of millennials generation. Research shows that millennials focus more on personal growth. This trend assumes the priority of personal values in everyday life, as well as in the professional and business sphere. The question, then, is whether such a model of interaction fits into the future business environment of Industry 4.0. Based on the fact that Industry 4.0 is focused on teamwork, openness and mutual understanding, we can talk about the greater favor of the new business environment to millennials. At the same time, the personal orientations of the new generation can cause changes in the future business environment that will reflect more progressive beliefs and attitudes [6].

\section{CONCLUSIONS}

The study examined the impact of digitalization of society on labor relations, as well as on the labor market. On the basis of the analysis the following conclusions were made:

1) Penetration of digital technologies into various sectors of the economy generates contradictory trends associated with both an increase in demand for highly skilled specialists and a fall in demand for labor.

2) One of the key challenges associated with digitalization of business processes is the need to develop digital skills. This problem is relevant for both business and the public sector, both for consumers and for suppliers of products and services.
3) Changes in labor relations in line with digital transformations have both a positive side (cost reduction, balancing of labor supply and demand on a global scale) and a negative effect (low level of social security and high volatility of income).

\section{DISCUSSION}

However, the study identified issues that require additional research, such as:

- transformation of the structure of professions and education profiles;

- change in personnel management principles;

- appearance of new social face of workers.

References:

1. OECD (2019) "Going Digital: Shaping Policies, Improving Lives", available at: http://dx.doi.org/ 10.1787/9789264312012-en (Accessed 13 Oct 2019).

2. OECD (2019) "OECD Digital Economy Outlook 2017", available at: http://dx.doi.org/10.1787/ 9789264276284-en (Accessed 13 Oct 2019).

3. Bogenhold, D. Klinglmair, R. and Kandutsch, F. (2019), "Self-employment on the way in a digital economy: A variety of shades of grey", available at: https://mpra.ub.unimuenchen.de/85321/(Accessed 13 Oct 2019).

4. OECD (2019) "Jobs and skills in the digital economy", available at: http://oecdobserver.org/news/fullstory.php/aid/5586/Jobs_and_skills_in_the_digital_economy.html (Accessed 13 Oct 2019).

5. The official site of State Statistics Service of Ukraine (2019), "Employment and unemployment", available at: http://ukrstat.gov.ua (Accessed 13 Oct 2019.

6. Cresnar, R. and Jevsenak, S. (2019), "The Millennials' Effect: How Can Their Personal Values Shape the Future Business Environment of Industry 4.0?", Na?e Gospodarstvo, vol. 65(1), pp. 57-65, available at: https://doi.org/ 10.2478/ngoe-2019-0005 (Accessed 13 Oct 2019).

Стаття надійшла до редакиї 15.10.2019 p.

\section{www. dy.nayka.com.ua}

Електронне фахове видання

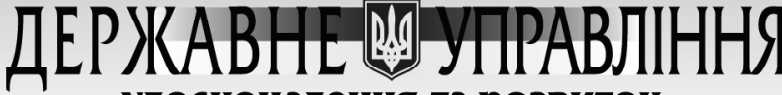 удосконалення та розвиток}

\section{Виходить 12 разів на рік}

$$
\begin{aligned}
& \text { Видання включено до переліку } \\
& \text { наукових фахових видань України } \\
& \text { з ДЕРЖАВного УПРАВЛІння } \\
& \text { e-mail: economy_2008@ukr.net } \\
& \text { тел.: (044) 223-26-28 } \\
& \text { (044) 458-10-73 }
\end{aligned}
$$

